\title{
Phototrophic and apochlorotic components of picoplankton and nanoplankton in the North Atlantic: geographic, vertical, seasonal and diel distributions
}

\author{
Paul G. Davis ${ }^{*}$, David A. Caron ${ }^{3}$, Paul W. Johnson ${ }^{2}$ and John McN. Sieburth ${ }^{2 * *}$ \\ ${ }^{1}$ Department of Zoology and ${ }^{2}$ Graduate School of Oceanography, University of Rhode Island, Kingston, Rhode Island, USA \\ ${ }^{3}$ Lamont-Doherty Geological Observatory, Palisades, New York, USA
}

\begin{abstract}
Chloroplast-containing and apochlorotic cells of nanoplankton ( 2 to $20 \mu \mathrm{m}$ ), and chroococcoid cyanobacteria and total bacteria in the picoplankton $(0.2$ to $2.0 \mu \mathrm{m})$ were enumerated by epifluorescence microscopy from 39 estuarine and oceanic stations to assess numerical relations of apochlorotic nanoplankton with other components of the microbial plankton. Apparent relations between different plankton types were found over geographic separation as well as seasonal and diel cycles. Population densities of apochlorotic, heterotrophic nanoplankton (Hnano) and chloroplastcontaining, phototrophic nanoplankton (Prano) were similar, ranging from $10^{4}$ cells $\mathrm{ml}^{-1}$ in estuarine environments to $10^{2}$ cells $\mathrm{ml}^{-1}$ at oceanic stations. All microbial populations in the euphotic zone showed exponential decreases in concentration with increasing bottom depth. Vertical profiles showed decreasing abundance of all microbial populations with depth. Studies in Narragansett Bay, Rhode Island, indicated that Hnano, Pnano and total picoplankton (Tpico) followed trends similar to each other over winter/spring and summer blooms. Hnano were positively correlated with Tpico populations one week earlier, suggesting a predator/prey relationship. Diel studies at oceanic stations and in mesocosms in Narrangansett Bay revealed positive correlations between Tpico and Hnano populations which may represent small interval temporal changes. These data suggest an abundant and dynamic Hnano population in the marine plankton which reflects changes observed in other components of the microbial plankton.
\end{abstract}

\section{INTRODUCTION}

Picoplankton and nanoplankton have recently been defined as size classes of planktonic organisms between 0.2 and $2.0 \mu \mathrm{m}$, and 2 and $20 \mu \mathrm{m}$, respectively; both include photosynthetic and non-phatosynthetic organisms (Sieburth et al., 1978). Although some cell types overlap between the 2 groups, picoplankton are primarily composed of prokaryotes, which include organotrophs, chemotrophs and phototrophs, and nanoplankton are predominated by eukaryotic protists. Study of size classes within the plankton by a variety of analytical and observational techniques has led to a

\footnotetext{
- Present address: SEAMOcean, Inc., P. O. Box 1627 , Wheaton, Maryland 20902, USA

- Addressee for reprint requests
}

realization of the importance of nanoplankton in the microbial food web. The smaller nanoplankton (less than $10 \mu \mathrm{m}$; principally microflagellates) are frequently found to dominate phytoplankton assemblages both numerically and by biomass (Ballantine, 1953; Beers et al., 1975, 1980, 1982; Booth et al., 1982; Hannah and Boney, 1983; Li et al., 1983). Similarly, this size fraction of the phytoplankton often accounts for most of the primary productivity (Malone, 1971; Van Valkenburg and Flemer, 1974; McCarthy et al. 1974; Durbin et al., 1975; Throndsen, 1978; Hannah and Boney, 1983; Li et al., 1983; Platt et al., 1983). Growth rates of phototrophic nanoplankton tend to exceed those of the large photosynthetic net plankton (Garrison, 1976), and the activity of these nanoplankters increases in dominance with distance from shore (Mommaerts, 1973). 
Apochlorotic nanoplankton members have received far less attention, and often nanoplankton has been assumed to be synonymous with or almost totally composed of photosynthetic organisms (Ballantine, 1953; Beers et al., 1975; Hannah and Boney, 1983). Sorokin (1977, 1979) presented data on apochlorotic flagellates from marine waters which showed high concentrations of these organisms and a biomass exceeding that of microzooplankton and bacteria. These data may be criticized since the differentiation between zooflagellates and phytoflagellates was accomplished at low magnification by visually observing the presence or absence of photosynthetic pigments. Linley et al. (1983) also enumerated relatively high densities of heterotrophic microflagellates for marine waters although the population and biomass estimates were lower than those of Sorokin. Linley et al. (1983) similarly differentiated between heterotrophic flagellates and phototrophic flagellates on the basis of conventional light microscopy, using settling chambers and inverted microscopy which may severely underestimate the abundance of the smaller flagellates (Davis and Sieburth, 1982). Beers et al. $(1980,1982)$ also enumerated large populations of microflagellates but did not distinguish between phototrophs and heterotrophs, although they estimated that 19 to $70 \%$ might be heterotrophs. Recent studies of apochlorotic, heterotrophic nanoplankton (Hnano) in marine waters, using epifluorescence microscopy to determine the presence or absence of chloroplasts (Davis et al., 1978; Davis and Sieburth, 1982; Fenchel, 1982c; Caron 1983; Sherr and Sherr, 1983), have confirmed the presence of large populations of apochlorotic nanoplankters, primarily composed of zooflagellates, and have yielded more precise estimates of their abundance.

The ecological role that these heterotrophic microflagellates play is not well established; it may be phagotrophic, osmotrophic, or mixotrophic. The bacterivorous nature of choanoflagellates (Laval, 1971; Leadbeater and Morton, 1975), bicoecids and bodonids (Kudo, 1966) is well known, and recent studies with isolates of estuarine apochlorotic microflagellates isolates showed obligate phagotrophy and no significant uptake of a variety of organic substrates (Haas and Webb, 1979). Linley et al. (1983) used their counts of the microbial plankton and productivity values from the literature to estimate that $66 \%$ of bacterial production in the plankton is consumed by heterotrophic flagellates, with the remainder being consumed by the microplankton or metazoans.

Alternatively, Beers et al. (1980) suggested that zooflagellates may act primarily as osmotrophs. Although flagellates have been grown axenically on rich organic media (Gold et al., 1970), the obvious bacterivory suggests that phagotrophy is the dominant trophic role.
Kopylov et al. (1980) estimated in laboratory studies of Parabodo attenuatus, that about $30 \%$ of its energy requirements were met by osmotrophy and the rest by phagotrophy, although these data may also be questioned since the experimental design assumed that flagellate predation on bacterial populations in batch culture did not affect bacterial growth rate or uptake of dissolved organics.

In order to recognize trophic diversity in the bacteria and microflagellates of the marine plankton, we have previously used the simple approach of counting the microbial plankton in the picoplankton and nanoplankton size classes to estimate prokaryotes and eukaryotes, and have further classified the populations into phototrophs and heterotrophs based upon the presence or absence of autofluorescing chloroplasts or thykalloids. Even though most cells in the nanoplankton are typically microflagellates with flagella frequently visible by epifluorescence microscopy, we have taken a conservative approach and designated the enumerated populations as phototrophic nanoplankton (Pnano) and heterotrophic nanoplankton (Hnano) following the convention of earlier publications (Burney et al., 1981, 1982; Davis and Sieburth, 1982; Sieburth and Davis, 1982). For the picoplankton, we have previously taken a similar approach and designated the phototrophic cyanobacteria as Ppico and the total picoplankton counts as Hpico, since we believed the latter to be overwhelmingly predominated by heterotrophic bacteria. However, it is becoming apparent that the picoplankton may include significant populations of phototrophic eukaryotes (Krempin and Sullivan, 1981; Johnson and Sieburth, 1982) and chemotrophic bacteria (Johnson et al., 1983; Sieburth, 1983). Therefore, the total picoplankton are now designated as Tpico and the Hpico term is discarded in recognition of the possible diversity of trophic types in the enumerated population.

This paper summarizes the data on nanoplankton and picoplankton populations enumerated by epifluorescence microscopy from sampling stations on 8 research cruises in the North Atlantic and in seasonal studies of Narragansett Bay, Rhode Island, USA. The relative abundance of Hnano and the apparent relations with other components of the plankton suggest that heterotrophic nanoplankton are an active and important part of the microbial plankton.

\section{MATERIALS AND METHODS}

Samples were taken from multiple depths at 32 stations in North Atlantic waters on 5 cruises from 1977 to 1981 (Fig. 1). These cruises included transects from Rhode Island to the Lesser Antilles of the Caribbean 


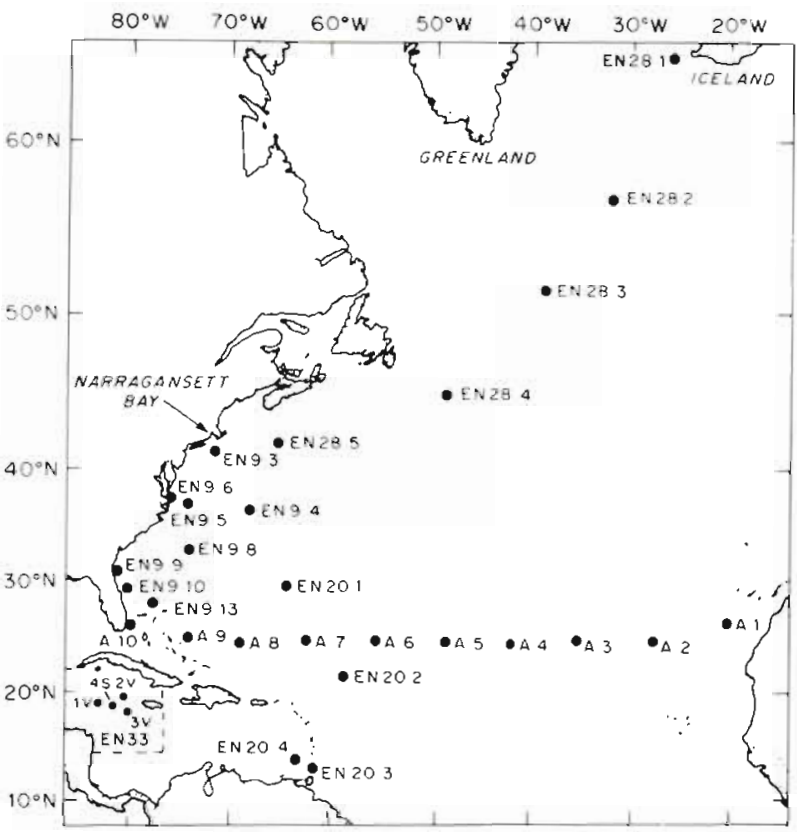

Fig. 1. Geographic location of cruise stations. EN9, EN20, EN28, and EN33 signify R/V 'Endeavor' cruises 009 (Jun 1977), 020 (Apr, 1978), 028 (Sep 1978), and 033 (Feb-Mar 1979), respectively. 'A': R/V 'Atlantis II' cruise 109:3 (August 1981). Station numbers for each cruise appear after cruise designation

(R/V 'Endeavor' cruise 020, Apr 1978), Iceland to Rhode Island (R/V 'Endeavor' cruise 028, Sep 1978), the Canary Islands to Florida (R/V 'Atlantis II' cruise 109:3, Aug 1981), and 3 shorter transects along the eastern seaboard of the United States (R/V 'Endeavor' cruise 009, Jun 1977), as well as several additional stations near the Cayman Islands in the Caribbean ( $R /$ $\mathrm{V}$ 'Endeavor' cruise 033, Feb 1979). A total of 279 samples were taken on these research cruises from the euphotic zone, the surface microlayer, and during diel studies (6 locations). All subsurface cruise samples were taken with acid-rinsed $(0.1 \mathrm{~N} \mathrm{HCl})$ Niskin bottles. Neuston samples were taken only on $R / V$ 'Endeavor' cruise 009 (EN-009) using both a screen sampler (Sieburth et al., 1976) and a glass plate sampler (Harvey and Burzell, 1972; Carlson, 1982), both pre-rinsed in $95 \%$ ethanol. Neuston samples were taken from an inflatable rubber boat (Zodiac) as it drifted into undisturbed water. On cruises EN-009 and EN-033, a Lambda Instruments (Lincoln, Nebraska) quantum sensor was used to establish the depth of the euphotic zone, judged as the $0.1 \%$ light level. Secchi disc readings were used on cruises EN-020 and EN-028. On all other cruises the depth of the euphotic zone at oligotrophic oceanic stations was judged to be at least $100 \mathrm{~m}$.

In addition to these samples, pico- and nanoplankton were enumerated from vertical profile samples obtained in the Western Sargasso Sea (3 stations between 29 and $34^{\circ} \mathrm{N}$ ), the Gulf Stream (3 stations between 30 and $34^{\circ} \mathrm{N}$ ) and in slope water of the North Atlantic (1 station at $38^{\circ} 40^{\prime} \mathrm{N}, 71^{\circ} 56^{\prime} \mathrm{W}$ ) on $\mathrm{R} / \mathrm{V}$ 'Oceanus' cruise 115 (Feb 1981), R/V 'Knorr Cruise' 94 (May 1982) and $R / V$ 'Columbus Iselin' cruise 83-01 (Feb 1983).

Diel studies of 24 to 48 h duration were performed on $\mathrm{R} / \mathrm{V}$ 'Endeavor' cruise 009 and 033 using parachute or window-shade drogued buoys, respectively, to maintain position within the same water mass. Sequential diel samples on EN-009 (Burney et al., 1981) were taken at an isotherm with depths determined by expendable bathythermographs (XBT) at the time of sampling. Sampling on EN-033 (Burney et al., 1982) was conducted at a fixed depth $(70 \mathrm{~m})$ in the mixed layer. Diel samples were taken at $4 \mathrm{~h}$ and $3 \mathrm{~h}$ intervals for EN-009 and EN-033, respectively.

Diel studies for Narragansett Bay were conducted in mesocosms of the Marine Ecosystems Research Laboratory (MERL) at the University of Rhode Island during July and November of 1979, and March of 1981. Samples were taken at intervals between 2 and $6 \mathrm{~h}$ over 24 to $72 \mathrm{~h}$. These mesocosms are $1.8 \mathrm{~m}$ in diameter and $5.5 \mathrm{~m}$ high, and frequent seawater additions and mixing simulate estuarine conditions (Vargo et al., 1982).

Narragansett Bay, Rhode Island, was sampled at intervals of 7 to $14 \mathrm{~d}$ during 1978 (32 d of sampling) and 1981 (23 d of sampling) to assess seasonal abundances and variability of plankton populations. During 1978 and 1981 samples were collected off the dock of the Graduate School of Oceanography, and, in 1978, concurrent samples were taken from MERL, mesocosms. During 1978, samples were siphoned through pre-rinsed tubing into clean collection bottles, and in 1981 samples were collected in an autoclaved bottle opened under water with a Wheaton extension sampler (Millville, NJ). All samples were preserved immediately with $0.5 \%$ ( $\mathrm{v} / \mathrm{v}$, final conc.) formaldehyde or glutaraldehyde (or both) and refrigerated in darkness until used.

Epifluorescence microscopy was used to enumerate nanoplankton and picoplankton populations in all samples. Hnano and Pnano were counted as described in Davis and Sieburth (1982) under dark room conditions after allowing sufficient time for the acclimation of the operator's eyes. This technique compares favorably with several others for the enumeration of Hnano (Davis and Sieburth, 1982; Caron, 1983). Bacteria (Tpico) were counted in all samples taken prior to 1980 by the method of Hobbie et al. (1977) using the fluorochrome acridine orange, but all subsequent samples were counted using 4',6-diamidino-2-phenyl-indole (DAPI; $1.0 \mu \mathrm{g} \mathrm{ml}^{-1}$ ), similar to the method of Porter and 
Feig (1980). Ppico were enumerated by autofluorescence as described in Johnson and Sieburth (1979). Counts for nearly all plankton populations were performed on an Olympus Vanox epifluorescence microscope using Olympus silicone oil immersion objectives: $40 \times$ for nanoplankton and $100 \times$ for picoplankton. Ppico, Hnano and Pnano on R/V 'Atlantis II', R/V 'Oceanus', R/V 'Knor' and R/V 'Columbus Iselin' cruises were enumerated using a Zeiss standard epifluorescence microscope. Vertical profile samples for both picoplankton and nanoplankton were counted using a $100 \times$ objective. Comparison of counts made using the 40 and $100 \times$ objectives for the same oceanic samples showed differences of only a few percent and consistently below the expected counting error associated with the technique. Nanoplankton and Tpico were counted in all estuarine and oceanic samples, and Ppico were counted in all cruise samples with the exception of those from EN-009. For all planktonic components, sufficient numbers of cells and fields were counted to yield a within sample confidence interval of $\pm 12 \%$ or less at $\alpha=0.05$ (Cassell, 1965).

\section{RESULTS AND DISCUSSION}

Average populations of nanoplankton and picoplankton in the euphotic zone at 32 different stations showed expected decreases in abundance with increasing depth of the water column (Fig. 2A; Table 1). This decrease was significantly correlated with $\log$ bottom depth for all plankton fractions $(\alpha=$ 0.05 ) and the lines are drawn from linear regression analysis. Population densities of Hnano from stations with shallow bottom depths (Table 1) averaged $60 \%$ of the density of Pnano over 3 stations and 2 seasonal cycles in Narragansett Bay (1978, 1981). In general, there was surprising parity in average population abundance between the Pnano and Hnano in the euphotic zone within the ranges of bottom depths given in Table 1, although the population densities varied considerably. Population densities decreased to approximately 700 cells $\mathrm{ml}^{-1}$ where bottom depths exceeded $200 \mathrm{~m}$. Average Tpico decreased from $2 \times 10^{6} \mathrm{ml}^{-1}$ in estuarine areas to $4 \times 10^{5} \mathrm{ml}^{-1}$ in oligotrophic regions. Average Ppico populations

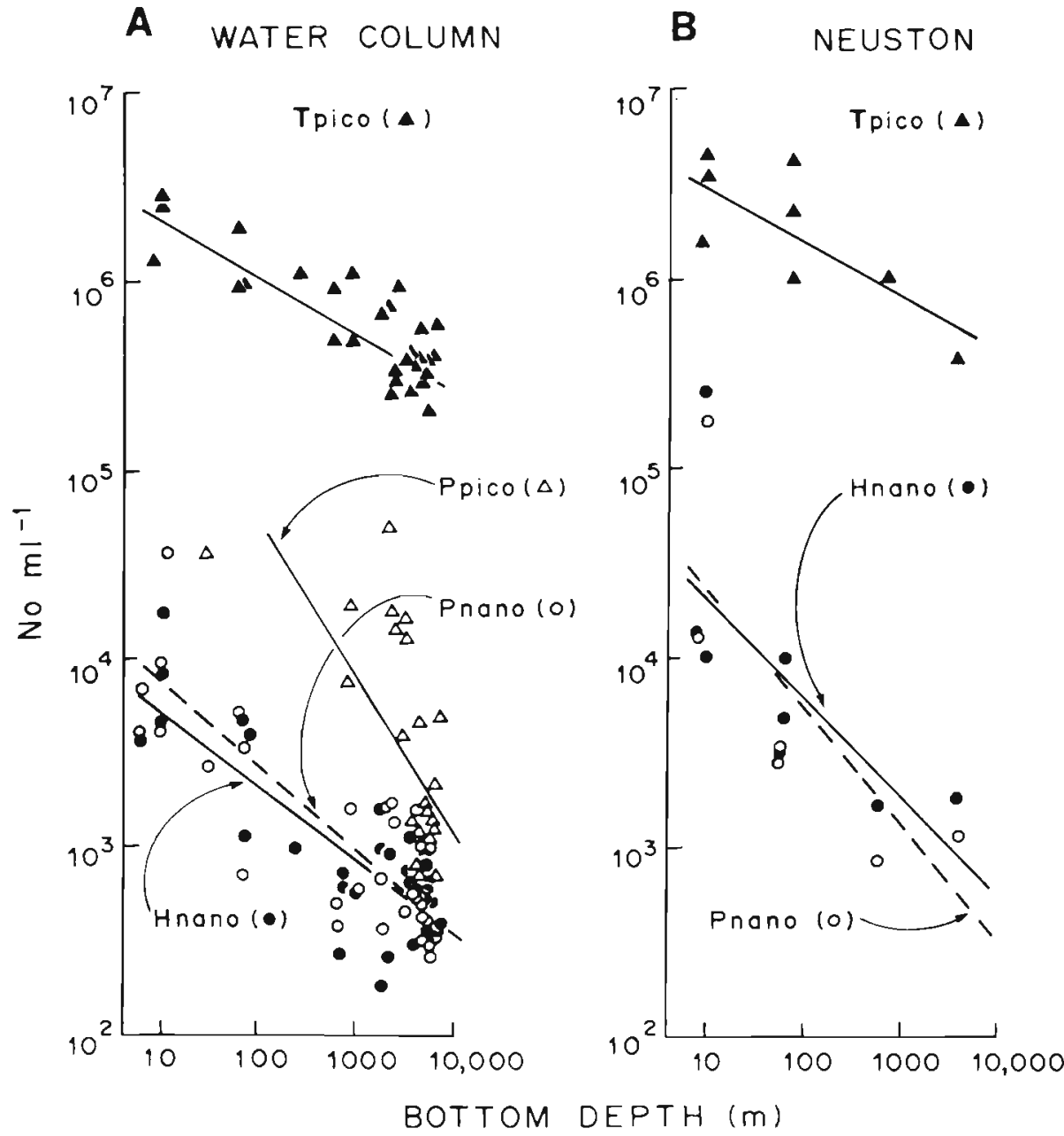

Fig. 2A, B. Distribution of plankton fractions with depth of the water column for euphotic zone and neuston samples. Averages of samples within euphotic zone; neuston samples are averages of screen and glass plate samples 
Table 1. Average nanoplankton and picoplankton popula tions for euphotic zone and surface microlayer samples within range of bottom depths

\begin{tabular}{|c|c|c|c|c|}
\hline & \multicolumn{4}{|c|}{ Range of bottom depth $(\mathrm{m})$} \\
\hline & $\begin{array}{c}0-20 \\
\text { Estua- } \\
\text { rine }\end{array}$ & $\begin{array}{c}20-200 \\
\text { Cont. } \\
\text { shelf }\end{array}$ & $\begin{array}{l}200-2000 \\
\text { Cont. } \\
\text { Slope }\end{array}$ & $\begin{array}{c}2000-6000 \\
\text { Deep } \\
\text { ocean }\end{array}$ \\
\hline \multicolumn{5}{|l|}{ Subsurface } \\
\hline \multicolumn{5}{|c|}{$\begin{array}{l}\text { Nanoplankton } \\
\left(\times 10^{3} \mathrm{ml}^{-1}\right)\end{array}$} \\
\hline Hnano & 7.2 & 3.1 & 0.71 & 0.66 \\
\hline Pnano & 12.0 & 2.9 & 0.71 & 0.77 \\
\hline \multicolumn{5}{|c|}{$\begin{array}{l}\text { Picoplankton } \\
\left(\times 10^{5} \mathrm{ml}^{-1}\right)\end{array}$} \\
\hline Tpico & 23.0 & 13.0 & 8.0 & 3.9 \\
\hline Ppico & nd & nd & 0.03 & 0.005 \\
\hline \multicolumn{5}{|c|}{$\begin{array}{l}\text { Nanoplankton } \\
\left(\times 10^{3} \mathrm{ml}^{-1}\right)\end{array}$} \\
\hline Hnano & 90.0 & 5.8 & 1.5 & 1.6 \\
\hline Pnano & 70.0 & 5.7 & 0.83 & 1.2 \\
\hline \multicolumn{5}{|c|}{$\begin{array}{l}\text { Picoplankton } \\
\left(\times 10^{5} \mathrm{ml}^{-1}\right)\end{array}$} \\
\hline Tpico & 31.0 & 25.0 & 11.0 & 3.6 \\
\hline
\end{tabular}

decreased sharply from $3 \times 10^{4} \mathrm{ml}^{-1}$ to $5 \times 10^{3} \mathrm{ml}^{-1}$ over a narrower range of samples (bottom depths from 290 to $6,000 \mathrm{~m}$ ). However, in coastal waters Ppico abundance may vary greatly (4 orders of magnitude) with season (Krempin and Sullivan, 1981) and any relation between Tpico and bottom depth would be highly dependent upon the time of sampling.

Neuston samples were taken only for EN-009 stations but a similar relation was found between population density and bottom depth. Populations of both nanoplankton and picoplankton were generally elevated relative to subsurface samples (Table 1; Fig. 2B), especially in nearshore stations of shallow bottom depth. For this analysis, no distinction was made between population counts from glass plate or screen samples, although the former method apparently samples a thinner portion of the surface microlayer (Carlson, 1982) and values averaged 3-fold higher by this method. Since both methods dilute the surface microlayer with subsurface water, these values may substantially underestimate neuston populations (Sieburth, 1976; Sieburth et al., 1976). Hnano concentrations were usually somewhat higher than those for Pnano, supporting the concept of the surface microlayer as an enriched heterotrophic microenvironment. Sieburth et al. (1976) have previously reported elevated DOC and carbohydrate concentrations, as well as bacterial and amoebae populations, in the surface microlayer.
The decrease in population densities with increasing depth of the water column is an expected result since, at least on a large scale, bottom depth is inversely related to phytoplankton abundance and primary productivity of the overlying waters (Malone, 1971; Beers et al., 1975, 1980). For picoplankton and nanoplankton populations counted in the present study, these decreases averaged about one order of magnitude in samples from nearshore to the oligotrophic oceans. Decreases in biomass for the picoplankton fractions would be somewhat higher. Unpublished data indicate that average bacterial volume is smaller in oceanic populations $\left(0.04 \mu \mathrm{m}^{3}\right)$ than in estuarine populations $\left(0.09 \mu \mathrm{m}^{3}\right)$. Seventy \% of all nanoplankton cells on average were about 2 to $3 \mu \mathrm{m}$ diameter for oceanic stations (nearly $100 \%<8 \mu \mathrm{m}$ diameter, 'Atlantis II' cruise) compared to $50 \%$ at 2 to $3 \mu \mathrm{m}$ diameter for Narragansett Bay (1981), but the variability was great and this difference is not significant $(\alpha=0.05)$. The flagellates appear to be dominated by naked monads including Bodo- and Monas-like flagellates (Davis and Sieburth, 1983).

The different plankton populations (combining both surface microlayer and subsurface values) were linearly proportional to each other (Fig. 3A-D) over the 32 stations ( $\alpha=0.001$ ). Tpico vs. Ppico, and Hnano vs. Ppico were not significantly correlated even though all populations decreased with increasing bottom depth, but as stated earlier the reduced data set for Ppico combined with a high variability makes these comparisons weak. These data indicate the general proportionality in the plankton populations sampled from various locations. Linley et al. (1983) showed similar correlations between heterotrophic flagellates and bacterial biomass for North Atlantic waters. It should be noted that Hnano and Pnano are not independent measures, thus increasing the chance of a spurious correlation. However, the emphasis in this analysis is merely the illustration of general trends in proportionality and population abundance, and not to derive predictive regression equations.

We previously reported (Davis and Sieburth, 1982) that the ratio of Tpico (then termed Hpico) to Hnano depended upon the region of sampling: the ratio tended to exceed $10^{3}$ for the more oligotrophic areas and decrease for nearshore stations. This ratio is linearly related to log depth of the water column for a reduced data set of averaged values from samples of Narragansett Bay and stations taken during cruises EN-009 and EN-033 (Fig. 4). It was originally hypothesized that this change in the ratio could reflect a decrease in the nutritional value of oceanic bacteria for predatory flagellates (Hnano), as well as a decrease in bacterial productivity. Such differences would tend to result in proportionately lower populations of bac- 

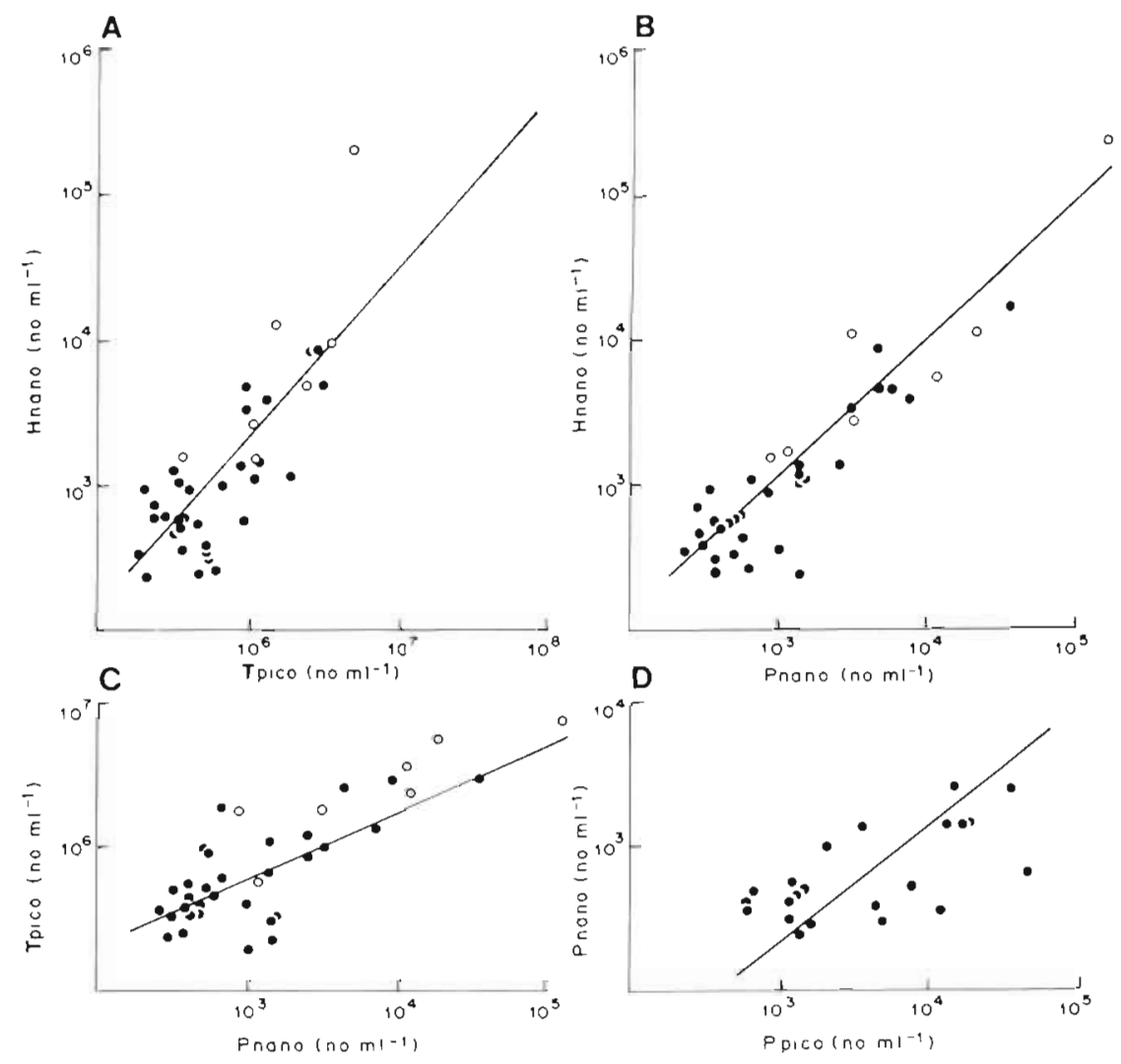

Fig. 3A-D. Proportional relations between plankton populations. A: Tpico vs. Hnano; B: Pnano vs. Hnano; C: Pnano vs. Tpico; D: Ppico vs. Pnano. Lines drawn by linear regression analysis

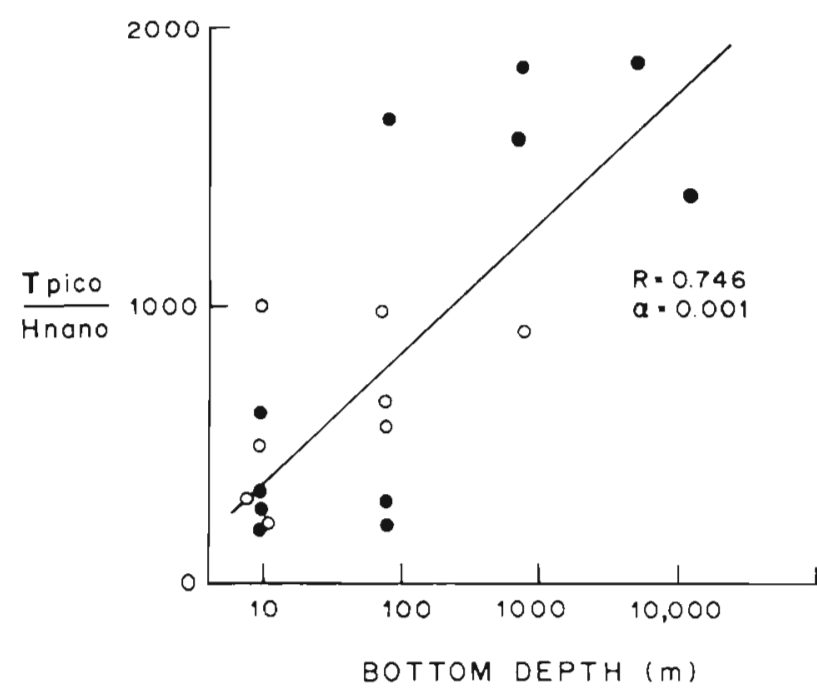

Fig. 4. Linear relations of ratio between bacteria (Tpico) to heterotrophic nanoplankton (Hnano) and log depth of water column for averaged neuston (open circles) and water column (closed circles) samples. R: correlation coefficient; $\alpha$ : level of significance

terivorous flagellates in the ocean than in nearshore waters assuming similar types of flagellates in the two regions. However, this relation is apparently more complex than initially thought, since no significant relation exists when data are pooled over all stations.
Ratios of Tpico to Hnano for the oceanic stations on Cruises EN-020, EN-028 and A109:3 were similar to those of nearshore samples.

Vertical distributions of pico- and nanoplankton populations are given in Fig. 5 for 3 oceanic environments. The Gulf Stream and Sargasso Sea profiles are averages of 3 profiles taken on different cruises. As expected, Pnano and Ppico abundance decreased more rapidly with increasing depth than Hnano and Tpico. In particular, Ppico populations decreased approximately 3 orders of magnitude from the surface to $500 \mathrm{~m}$. This decrease exceeded that of the Pnano, possibly due to differences in predation pressure or suitability of the physical environment. The parity between Pnano and Hnano noted previously (Fig. 3B; Table 1) is apparent throughout the euphotic zone in all 3 environments. Below the euphotic zone, however, heterotrophs dominate the nanoplankton.

Seasonal observations of Hnano, Pnano and Tpico in Narragansett Bay indicated generally similar patterns for these populations. Data for 1978 (Fig. 6 and 7A, C) show seasonal increases in all plankton components during February (winter/spring bloom) and the summer months. The winter-spring bloom has long been a recognized event for Narragansett Bay (Pratt, 1959, 1965; Smayda, 1973; Durbin et al., 1975) although phytoplankton are dominated at this time by chain- 


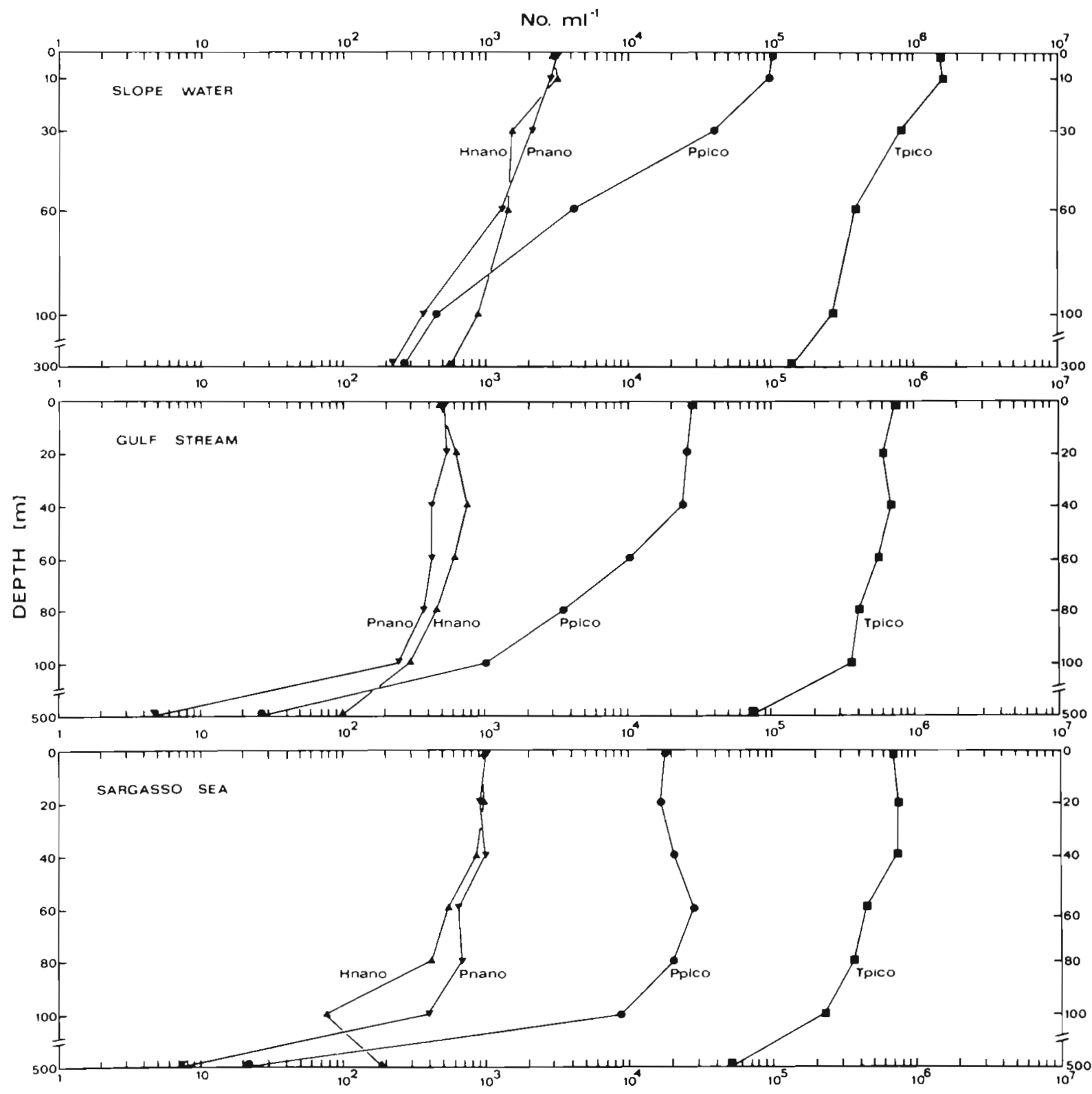

Fig. 5. Vertical distribution of pico- and nanoplankton populations in 3 oceanic environments. Data from 3 stations each were averaged to obtain the Gulf Stream and Sargasso Sea profiles. Slope water represents a single profile

forming centric diatoms. The summer increases in phytoplankton are typically associated with the nanoplankton (Durbin et al., 1975). Sharp decreases in nanoplankton populations, and to a lesser extent the bacteria (Tpico), occurred in August and lower populations characterized the remainder of the year with some indication of a mid-fall bloom, especially evident in the heterotrophic populations. Similar trends were observed by Durbin et al. (1975) in studies on Narragansett Bay. These same general patterns were also observed for all parameters during 1981. However, populations were lower on average in 1981 than in
1978 for Hnano $\left(1.9 \times 10^{3} \mathrm{ml}^{-1}\right.$ vs. $\left.8.5 \times 10^{3} \mathrm{ml}^{-1}\right)$ and Tpico $\left(1.95 \times 10^{6} \mathrm{ml}^{-1}\right.$ vs. $\left.2.48 \times 10^{6} \mathrm{ml}^{-1}\right)$.

Despite similarities in seasonal trends between Tpico and Hnano, there was no significant direct correlation between these populations in either Narragansett Bay or the MERL mesocosms. However, in the MERL mesocosms, Hnano population levels reflected Tpico populations observed 5 to 8 d earlier since Tpico concentration was positively correlated with Hnano populations in the following week's sample (Fig. 7B, D). Successive samples spaced $8 \mathrm{~d}$ or greater apart were not use in this analysis. This relationship sug- 


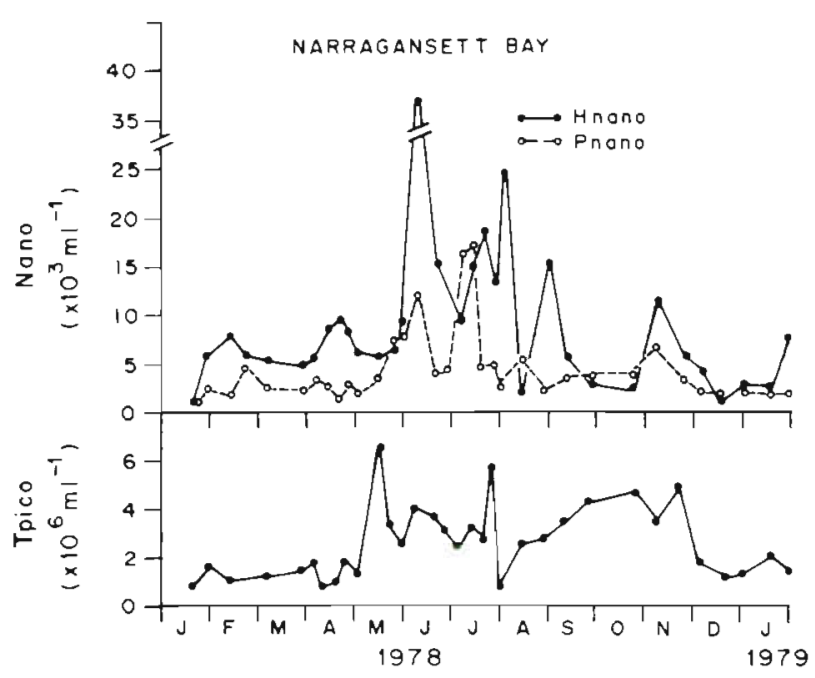

Fig. 6. Seasonal changes of nanoplankton and bacteria populations in Narragansett Bay, RI, during 1978

gests a trophic linkage between the 2 populations since major increases in a prey population might be expected to precede increases in a predator population.

Three diel studies conducted at oceanic stations on cruises EN-009 and EN-033, and 3 studies in the MERL mesocosms revealed a significant direct correlation between Hnano and Tpico (Fig. 8). In addition, in a diel study conducted at Station 4 (EN-009), Hnano was positively $(\alpha=0.001)$ related to both Tpico and ATP (greater than $1 \mu \mathrm{m}$ size fraction) by multiple linear regression (unpubl. own data). While such relations were not apparent in all diel studies, a significant positive correlation between Tpico and Hnano existed for 4 of 9 oceanic diel studies, and 3 of $12 \mathrm{MERL}$ studies. This is a frequent enough occurrence to suggest that some linkage between these populations may exist, and that these correlations are not the result of pure chance (Pearson Chi square analysis, $\alpha=0.005$ ). There are many possible reasons for a lack of correlation in some of the studies, including predation of Hnano upon populations of microorganisms other than Tpico (e.g. Ppico, Pnano).

The interpretation of the results of the oceanic diel studies is not entirely clear. As discussed in Burney et al. (1981), diel studies on EN-009 may represent the sampling of small-scale spatial heterogeneities since the positioning of the Niskin bottles on an exact isotherm was not precise. Similarly, the diel data shown from EN-033 may represent spatial heterogeneity since, for Station $4 \mathrm{~s}$, Hnano was correlated with temperature change, even though sampling was conducted in the mixed layer and sigma-t variation was less than $0.3 \%$ (Burney et al., 1982). Nevertheless, even if the 'diel' fluctuations in Hnano and Tpico populations really reflect small-scale spatial
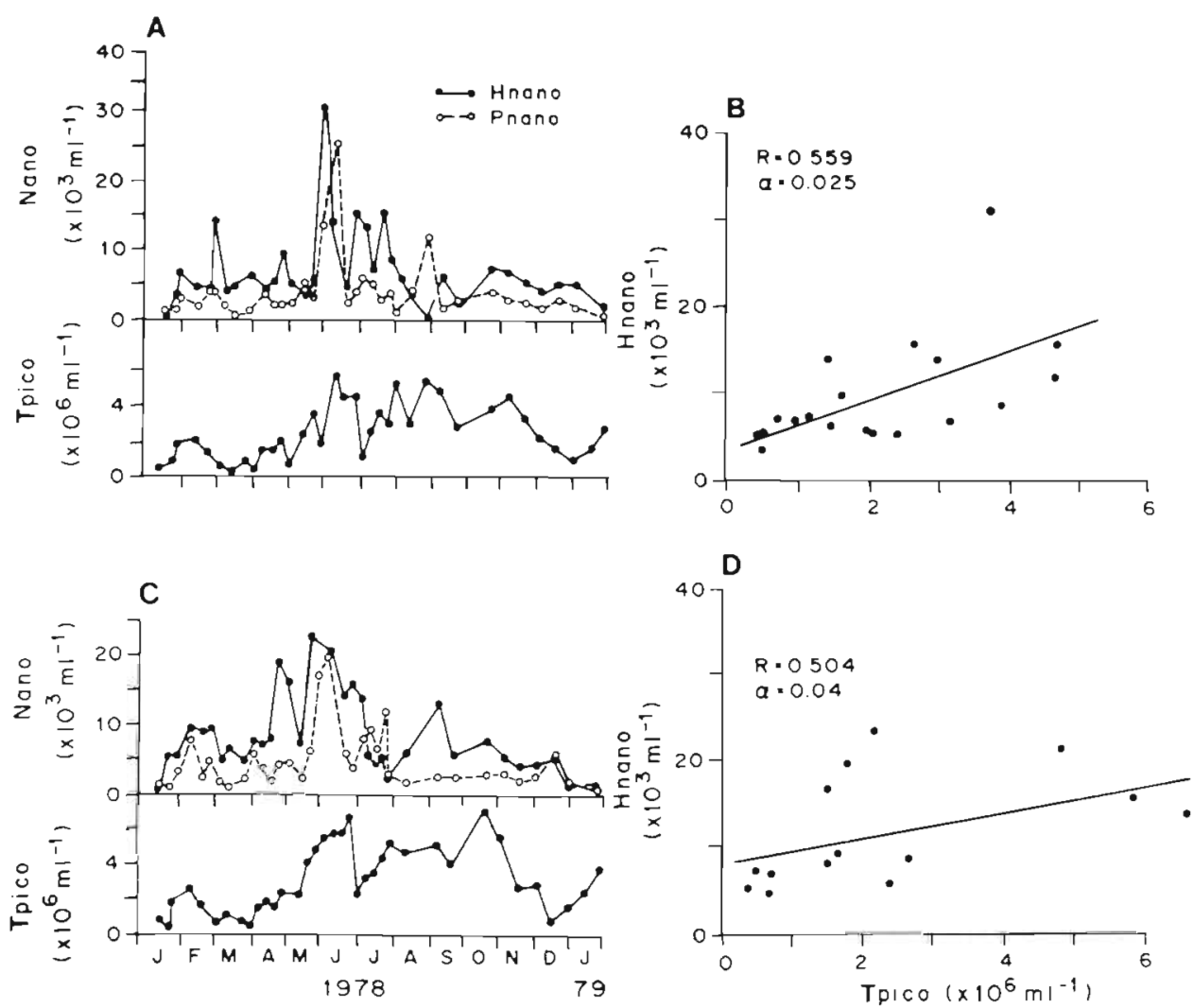

Fig. 7 A, C: Seasonal changes of nanoplankton and bacteria populations in mesocosms (A: Tank 1; C: Tank 5) of the Marine Ecosystems Research Laboratory (MERL), Narragansett, RI. Fig. 7B, D: Direct linear relations between bacteria (Tpico) and heterotrophic nanoplankton (Hnano) in the next sample (1 wk later); $B$ : Tank 1; D: Tank 5 

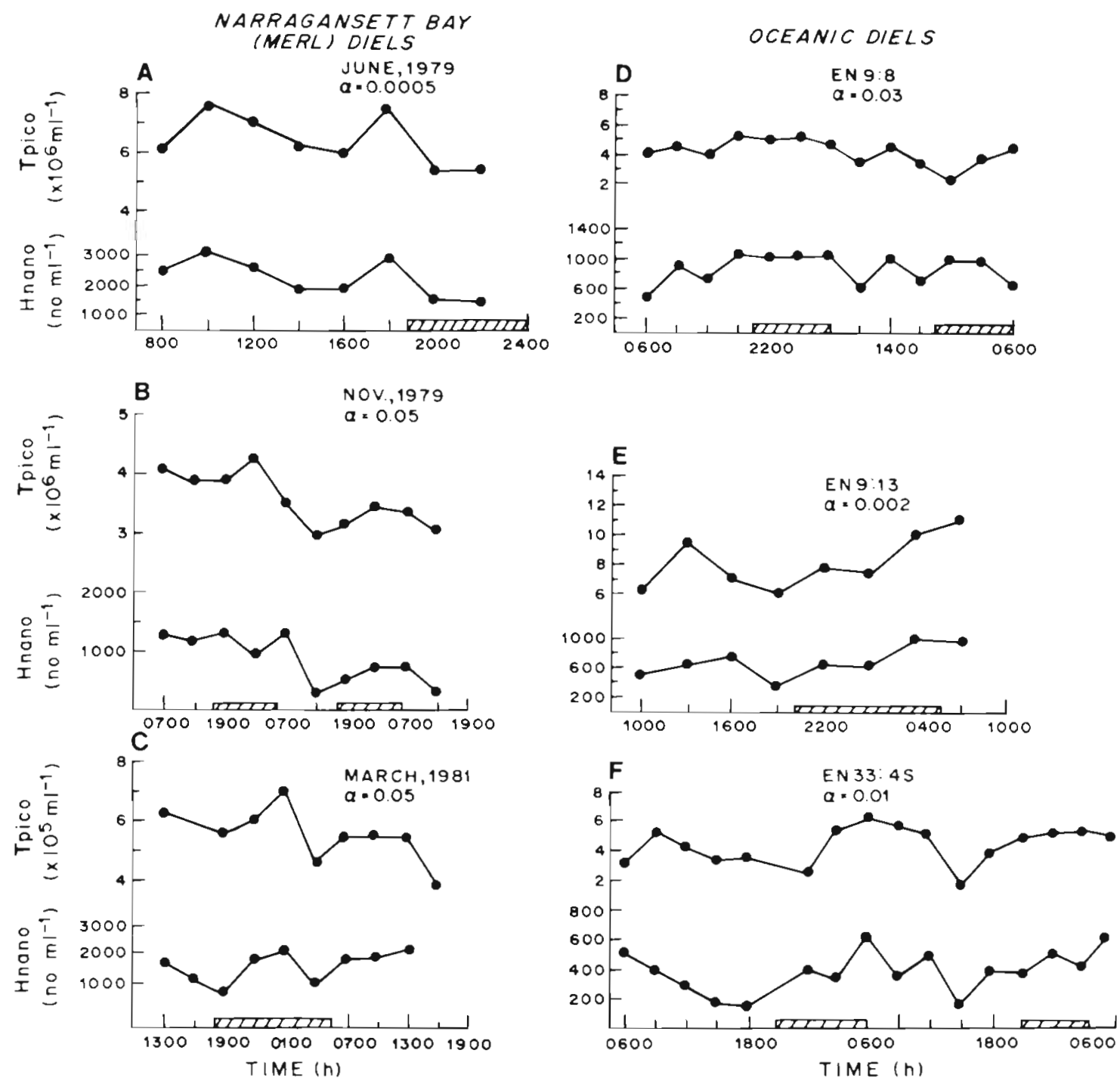

Fig. 8. Bacteria (Tpico) and heterotrophic nanoplankton (Hnano) population changes in diel studies from MERL mesocosms $(A-C)$, and oceanic drift stations (D-F). $\alpha$ : level of significance

variation, this evidence by itself suggests some linkage between the 2 populations. In the MERL diel studies the water masses sampled were contained, and all sampling was preceded by $15 \mathrm{~min}$ of mechanical mixing which has been previously demonstrated to provide a well mixed mesocosm (Vargo et al., 1982), although some small-scale heterogeneities might still exist associated with suspended particles.

A direct correlation between Hnano and Tpico over time does not indicate whether Hnano is an osmotrophic or phagotrophic population since a positive correlation could result from either case. If Hnano utilize Tpico as prey, then the data suggest that Hnano rapidly alters its growth rate with changing bacterial production. Assuming all changes in Hnano concentrations were due to temporal and not spatial differences, the most rapid increases observed for Hnano over a sampling interval would be equal to a doubling time of $2.5 \mathrm{~h}$, which is close to maximal rates observed for zooflagellates in the laboratory (Davis, 1982; Fenchel 1982b; Sherr et al., 1983). Decreases in Hnano with decreases in bacterial concentrations would likely be a result of continued predation pressure on the Hnano from microzooplankton or other predators. In other diel studies from EN-009 and EN-033 where a direct relation between Tpico and Hnano was not apparent, Burney et al. (1981, 1982) reported direct relations of Hnano with carbohydrate change over diel periods, which suggest the release of organics by Hnano as a result of predation since Tpico was inversely correlated with the diel carbohydrate change. Such observable relations over diel cycles, however, seemingly 
contradict the results of the seasonal study in which bacterial populations were significantly related to Hnano populations one week later (Fig. 6 and 7B, D). One possible explanation for this difference might result from the larger scale of the bacterial changes occurring over $1 \mathrm{wk}$ periods, including increases of $500 \%$. Adjustment of Hnano population levels to large scale changes in bacterial populations may require more time even while short interval changes remain positively correlated. Fenchel (1982b) noted that heterotrophic flagellate populations showed a peak in abundance about $4 \mathrm{~d}$ after a bacterial peak. Mathematical modelling of predator-prey systems has shown that the enrichment of a prey population may induce stable limit cycles from populations previously at a stable equilibrium point (Gilpin, 1972; May, 1974).

Evidence for Hnano phagotrophy of Tpico is indicated from other sources. Bacterivorous flagellates have been cultured and rates of predation upon bacteria have been estimated (Kopylov et al., 1980; Davis, 1982; Fenchel, 1982a; Sherr et al., 1983; Davis and Sieburth, unpubl.). In addition, heterotrophic flagellates of similar morphologies to known bacterivores have been shown to account for 40 to $100 \%$ of Hnano from Narragansett Bay and the Sargasso Sea (Davis, 1982; Davis and Sieburth, 1983).

It is important not to over-interpret the significance and meaning of in situ relations observed in population counts. Measurements and 'experiments' conducted by direct sampling of the environment and the estimation of plankton populations are not controlled in the sense of a well designed laboratory experiment, and any relations observed between different plankton fractions may be the result of many possible causes. Rarely does environmental data provide absolute evidence for a hypothesized mechanism or theory. Similarly, the absence of observable relations in the environment does not indicate the absense of hypothesized underlying mechanisms. However, if identifiable and repeatable relations between plankton populations are observed, such data indicate either direct interaction between the plankton groups or the effect of an external controlling factor. Questions of the exact mechanisms controlling these relations are most easily approached by laboratory experiments and observations, but observable in situ relations provide field data which help to verify predictions made from the laboratory. In this context, the relations observed in this study may be factored into several possible explanations of the interactions between the components of the microbial plankton. However, given the knowledge that the Hnano are primarily composed of colorless flagellates, and knowledge of the bacterivorous nature of these flagellates as established through laboratory experimentation, it seems likely that much of the observed relations between Tpico and Hnano are the result of some interaction of prey and predator. By itself, the diel and seasonal data show a rapidly changing and dynamic Hnano population, and the geographic and vertical profile data show that the Hnano follow the expected trends of other plankton populations. This evidence added to the knowledge gained by several other studies on the heterotrophic flagellates by many authors suggest an active and important phagotrophic microflagellate population responsible, in part, for the transfer of bacterial biomass to higher levels in the food web.

Acknowledgements. The authors are grateful to J. Fontaine, R. Heffernan, and M. Sieracki for assistance with sampling and enumeration of samples, to J. Knapp and J. Millar Davis for aid in manuscript preparation, to L. Madin for providing valuable ship time, and to N. Hairston, Jr. for critical review. This work was supported by the Biological Oceanography Program of the National Science Foundation (Grants OCE8121881, OCE74-01537A02, OCE76-81779, OCE80-24441, OCE78-26388, OCE80-18514), by the Environmental Protection Agency (MERL grant R-806072), and by the Woods Hole Oceanographic Institution education program.

\section{LITERATURE CITED}

Ballantine, D. (1953). Comparison of the different methods of estimating nanoplankton. J. mar. biol. Ass. U.K. 32: 129-147

Beers, J. R., Reid, F. M. H., Stewart, G. L. (1975). Microplankton of the North Pacific Central Gyre: population structure and abundance. Int. Revue ges. Hydrobiol. 60: 607-638

Beers, J. R., Reid, F. M. H., Stewart, G. L. (1980). Microplankton population structure in southern California nearshore waters in late spring. Mar. Biol. 60: 209-226

Beers, J. R., Reid, F. M. H., Stewart, G. L. (1982). Seasonal abundance of the microplankton population in the North Pacific Central Gyre. Deep Sea Res. 29: 227-245

Booth, B. C., Lewin, J., Norris, R. E. (1982). Nanoplankton species predominant in the subarctic Pacific in May and June 1978. Deep Sea Res. 29: 185-200

Burney, C. M., Davis P. G., Johnson, K. M., Sieburth, J. McN. (1981). Dependence of dissolved carbohydrate concentrations upon small scale nanoplankton and bacterioplankton distributions in the western Sargasso Sea. Mar. Biol. 65: 289-296

Burney, C. M., Davis, P. G., Johnson, K. M., Sieburth, J. McN. (1981). Diel relationships of microbial trophic groups and in situ dissolved carbohydrate dynamics in the Caribbean Sea. Mar. Biol. 67: 311-322

Carlson, D. J. (1982). A field evaluation of plate and screen microlayer sampling techniques. Mar. Chem. 11: 189-208

Caron, D. A. (1983). Technique for enumeration of heterotrophic and phototrophic nanoplankton, using epifluorescence microscopy, and comparison with other procedures. Appl. environ. Micriol. 46: 491-498

Cassell, E. A. (1965). Rapid graphical method for estimating precision of direct microscopic counting data. Appl. Microbiol. 13: 293-296

Davis, P. G. (1982). Bacterivorous flagellates in marine waters. Doctoral dissertation, University of Rhode Island, Kingston 
Davis, P. G., Caron, D. A., Sieburth, J. McN. (1978). Distribution and abundance of nanoplankton in estuarine, shelf and oceanic waters of the North Atlantic. J. Protozool. $25: 25 \mathrm{~A}$

Davis, P. G., Sieburth, J. McN. (1982). Differentiation of the phototrophic and heterotrophic nanoplankton populations in marine waters by epifluorescence microscopy. Annls. Inst. océanogr., Paris 58(S): 249-260

Davis, P. G., Sieburth, J. McN. (1983). Comparison of cultured and natural populations of heterotrophic microflagellates from estuarine and oceanic waters. J. Protozool. 30: $22 \mathrm{~A}-23 \mathrm{~A}$

Durbin, E. G., Krawiec, R. W., Smayda, T. J. (1975). Seasonal studies on the relative importance of different size fractions of phytoplankton in Narragansett Bay (USA). Mar. Biol. 32: 271-287

Fenchel, T. (1982a). Ecology of heterotrophic microflagellates. I. Some important forms and their functional morphology. Mar. Ecol. Prog. Ser. 8: 211-223

Fenchel, T. (1982b). Ecology of heterotrophic microflagellates. II. Bioenergetics and growth. Mar. Ecol. Prog. Ser. 8: 223-231

Fenchel, T. (1982c). Ecology of heterotrophic microflagellates. IV. Qualitative occurrence and importance as bacterial consumers. Mar. Ecol. Prog. Ser. 9: 35-42

Garrison, D. L. (1976). Contribution of the net plankton and nannoplankton to the standing stocks and primary productivity in Monterey Bay, California, during the upwelling season. U.S. natn. Mar. Fish. Serv. Fish. Bull. 74 183-194

Gilpin, M. E. (1972). Enriched predator-prey systems: theoretical stability. Science, N.Y. 177:902-904

Gold, K., Pfister, R. M., Liguori, V. R. (1970). Axenic cultivation and electron microscopy of two species of choanoflagellida. J. Protozool. 17:210-212

Haas, L. W., Webb, K. L. (1979). Nutritional mode of several non-pigmented microflagellates from the York River estuary, Virginia. J. exp. mar. Biol. Ecol. 39: 125-134

Hannah, F. J., Boney, A. D. (1983). Nanophytoplankton in the Firth of Clyde, Scotland: seasonal abundance, carbon fixation and species composition. J. exp. Mar. Biol. Ecol. 67: 105-147

Harvey, G. W., Burzell, L. A. (1972). A simple microlayer method for small samples. Limnol. Oceanogr. 17: 156-157

Hobbie, J. E., Daley, R. J., Jasper, S. (1977). Use of Nuclepore filters for counting bacteria by fluorescence microscopy. Appl. environ. Microbiol. 33: 1225-1228

Johnson, K. M., Davis, P. G., Sieburth, J. McN. (1983). Diel variation of $\mathrm{TCO}_{2}$ in the upper layer of oceanic waters relects microbial composition, variation, and possibly methane cycling. Mar. Biol. 77: 1-10

Johnson, P. W., Sieburth, J. McN. (1979). Chroococcoid cyanobacteria in the sea: a ubiquitous and diverse phototrophic biomass. Limnol. Oceanogr. 24: 928-935

Kopylov, A. I., Mamayeva, T. I., Batsanin, SWF. (1980). Energy balance of the colorless flagellate Parabodo attenuatus (Zoomastigophora, Protozoa). Oceanology 20: 705-708

Krempin, D. W., Sullivan, C. W. (1981). The seasonal abundance, vertical distribution, and relative microbial biomass of chroococcoid cyanobacteria at a station in Southern California coastal waters. Can. J. Microbiol. 27: $1341-1344$

Kudo, R. R. (1966). Protozoology, 5th ed. C. C. Thomas Publ., Springfield, Ill.

Laval, M. (1971). Ultrastructure et mode de nutrition du Choanoflagelle Salpingoeca pelagica, sp. nov.: com- paraison avec les choanocytes des Spongiaires. Protistologica $7: 325-336$

Leadbeater, B. S. C., Morton, C. (1975). A microscopical study of a marine species of Codosiga James-Clark (Choanoflagellata) with special reference to the ingestion of bacteria. Biol. J. Linnean Soc. Lond. 6: 337-348

Li, W. K. W., Subba Rao, D. V., Harrison, W. G., Smith, J. C. Cullen, J. J., Irwin, B., Platt, T (1983). Autotrophic picoplankton in the tropical ocean. Science, N.Y. 219: 292-295

Linley, E. A. S., Newell, R. C., Lucas, M. I. (1983). Quantitative relationships between phytoplankton, bacteria and heterotrophic microflagellates in shelf waters. Mar. Ecol Prog. Ser. 12: 77-89

Malone, T. C. (1971). The relative importance of net plankton and nanoplankton as primary producers in neritic and oceanic tropical waters. Limnol. Oceanogr. 16: 633-639

May, R. M. (1974). Stability and complexity in model ecosystems. Princeton University Press, Princeton, N.J.

McCarthy, J. J., Taylor, W. R., Loftus, M. E. (1974). Significance of nanoplankton in the Chesapeake Bay estuary and problems associated with the measurement of nanoplankton productivity. Mar. Biol. 24: 7-16

Mommaerts, J-P. (1973). The relative importance of nannoplankton in the North Sea primary production. Br. Phycol. J. 8: $13-20$

Platt, T., Subba Rao, D. V., Irwin, B. (1983). Photosynthesis of picoplankton in the oligotrophic ocean. Nature, Lond. 301: 702-704

Porter, K. G., Feig, Y. S. (1980). The use of DAPI for identifying and counting aquatic microflora. Limnol. Oceanogr. 25: $943-948$

Pratt, D. M. (1959). The phytoplankton of Narragansett Bay. Limnol. Oceanogr. 4: 425-440

Pratt, D. M. (1965). The winter-spring diatom flowering in Narragansett Bay. Limnol. Oceanogr. 10: 173-184

Sherr, B., Sherr, E. (1983). Enumeration of heterotrophic microprotozoa by epifluorescence microscopy. Estuar, coast. Shelf Sci. 16: 1-7

Sherr, B. F., Sherr, E. B., Berman, T (1983). Growth grazing, and ammonia excretion rates of a heterotrophic microflagellate fed with four species of bacteria. Appl. environ. Microbiol. 45: 1196-1201

Sieburth, J. McN. (1976). Bacterial substrates and productivity in marine ecosystems. A. Rev. Ecol. Syst. 7: 259-285

Sieburth, J. McN. (1983). Microbiological and organic-chemical processes in the surface and mixed layers. In: Liss, $P$ S., Slinn, W. G. N. (ed.) A.ir-sea exchange of gases and particles. NATO Advanced Study Institute Series, D. Reidel Pugl. Co., Dordrecht, Holland, p. 121-172

Sieburth, J. McN., Davis, P. G. (1982). The role of heterotrophic nanoplankton in the grazing and nurturing of planktonic bacteria in the Sargasso and Caribbean Seas. Annls Inst. océanogr., Paris 58(S): 285-296

Sieburth, J. McN., Smetacek, V., Lenz, J. (1978). Pelagic ecosystem structure: heterotrophic compartments of the plankton and their relationship to plankton size fractions. Limnol. Oceanogr. 23: 1256-1263

Sieburth, J. MCN., Willis, P.-J., Johnson, K. M., Burney, C. M., Lavoie, D. M., Hinga, K. R., Caron, D. A., French, F. W. III, Johnson, P. W., Davis, P. G. (1976). Dissolved organic matter and heterotrophic microneuston in the surface microlayers of the North Atlantic. Science, N.Y 194: $1415-1418$

Smayda, T J. (1973). The growth of Skeletonema costatum during a winter-spring bloom in Narragansett Bay, Rhode Island. Norw. J. Bot. 20: 219-247 
Sorokin, Yu. I. (1977). The heterotrophic phase of plankton succession in the Japan Sea. Mar. Biol. 41: 107-117

Sorokin, Yu. I. (1979). Zooflagellates as a component of the community of eutrophic and oligotrophic waters in the Pacific Ocean. Oceanology 19: 316-319

Throndsen, J. (1978). Productivity and abundance of ultraand nanoplankton in Oslofjorden. Sarsia 63: 273-284
Van Valkenburg, S. D., Flemer, D. A. (1974). The distribution and productivity of nannoplankton in a temperate estuarine area. Estuar. coast. mar. Sci. 2: 311-322

Vargo, G. A., Hutchins, M., Almquist, G. (1982). The effect of chronic levels of No. 2 fuel oil on natural phytoplankton assemblages in microcosms. 1. Species composition and seasonal succession. Mar. environ Res. 6: 245-264

This paper was submitted to the editor; it was accepted for printing on September 6, 1984 